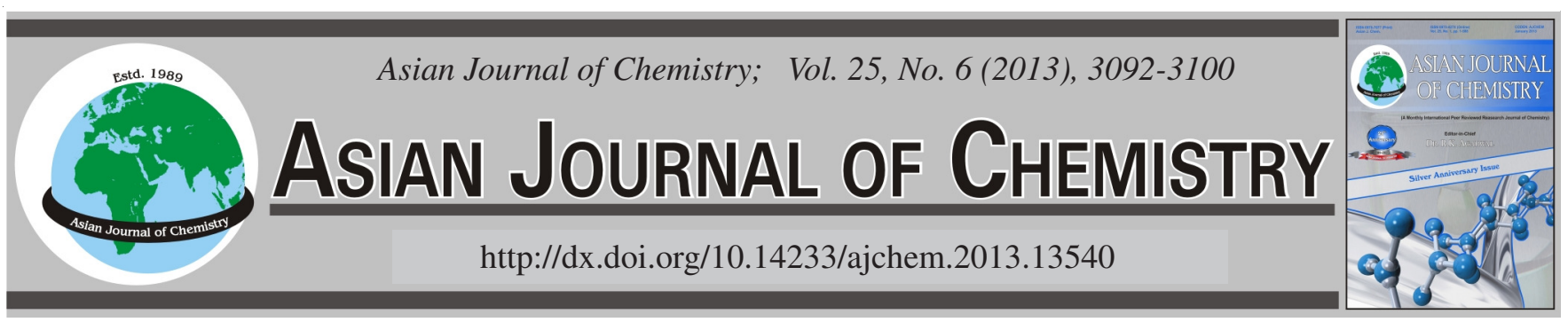

\title{
Size Charge Fractionation for the Characterization Investigation of Municipal Solid Waste Incinerator Fly Ash
}

\author{
Yanyu Wu, Xiaochun Peng* and Xiaoying Hu
}

South China Institute of Environmental Science, MEP, Guangzhou 510655, P.R. China

*Corresponding author: Fax: +86 20 85557690; Tel: +86 20 85541902; E-mail: pengxiaochun@scies.org

\begin{abstract}
A thorough examination has been undertaken for determining size dependent characterization of fly ash from municipal solid waste incinerators. The fly ash was segregated into five fractions and their size dependent characteristics, including particle size distribution, morphology, mineralogical and chemical composition, leaching behaviour of heavy metals of ash particles, levels of polychlorinated dibenzo- $p$-dioxins and polychlorinated dibenzofurans were analyzed and evaluated. The results revealed that various size particles of fly ash have different characteristic due to transportation and mixing system inside incinerators. Particle size distribution indicated that 72.2 , 82.4 and $91.4 \%$ of fly ash have lower than 75,125 and $187.5 \mu \mathrm{m}$, respectively. The leaching concentration of Pb in all fractions exceeded the regulatory level set by the China EPA. The leaching concentration of $\mathrm{Cu}, \mathrm{Zn}$ and $\mathrm{Pb}$ of fly ashes with sized range $125-187.5 \mu \mathrm{m}$ was lower than that of the others, whereas $\mathrm{Cr}$ had the highest concentration compared with other samples. The concentrations of higherchlorinated congeners of dioxins were remarkably higher than those of lower-chlorinated congeners. The poison effect of dioxins in the fly ash was mainly caused by polychlorinated dibenzofurans. This investigation demonstrated that the characterization of municipal solid waste incinerator fly ash had the potential size dependent information of particulate materials in relation to their production processes, chemical compositions, environmental fates and other factors. The result was also provided the valuable information for incinerator design and operation.
\end{abstract}

Key Words: Fly ash, Sized fraction, Dioxins, Heavy metals, Dioxins.

\section{INTRODUCTION}

The amount of municipal solid wastes increases rapidly with the growing urbanization and industrialization in China. According to National Bureau of Statistics of China (NBSC), the municipal solid waste generation was about 154.4 million tons and 2.4 million tons higher than in 2007. The disposal ratio of it was about $67 \%$ in 2008, $5 \%$ higher than in 2007. Incineration has become the second important municipal solid wastes disposal method instead of compost in China. By the end of 2008, there had been 74 incineration plants and about 15.7 million tons of municipal solid wastes was incinerated producing more than $0.8 \mathrm{Mt}$ fly ash ${ }^{1}$, where 8 incineration plants, 1.7 Mt incineration capacity and $0.1 \mathrm{Mt}$ fly ash were increased compared with in $2007^{2}$. The increase of fly ash has raised much concern since the content of hazardous materials makes this residue ecologically harmful ${ }^{3-7}$.

A thorough knowledge of its chemical properties is required to handle such ash effectively and safely. Previous works have studied the characteristics of fly ashes generated from municipal solid waste incinerator. Kida et al. ${ }^{8}$ and
NaKamura et al. ${ }^{9}$ have concentrated on the characteristics of heavy metal content and leaching behaviour in fly ash from a single municipal solid waste incinerator. Chang and Wey ${ }^{10}$ have compared the leaching behaviour of heavy metals of fly ashes from different municipal solid waste incinerators. In addition, the discussions on the effects of fly ash particle fractions is available somewhere ${ }^{11-13}$. Chang and Chung ${ }^{11}$ segregated fly ash samples into seven fractions and determined the correlation between dioxins content and physical and chemical properties of each fraction by analyzing BET surface area, density, chloride content, carbon content and heavy metal contents. Moon et al. ${ }^{12}$ fractionated insoluble fly ash particles with diameters lower $53 \mu \mathrm{m}$ into six different size groups to study the formation/removal mechanism of PCDD/Fs during combustion processes with gravitational SPLITT fractionation technique for the fast and continuous separation of micron sized particles. However, more required comprehensive physical and chemical characterizations of fly ash in terms of particle distribution have not been clear. Polychlorinated dibenzo- $p$ dioxins and dibenzofurans (PCDD/Fs), an undesired recalcitrant contaminants generated during incineration by various chlorinated 
chemicals, released into the environment from municipal and industrial waste incineration with long time toxic effect after contamination ${ }^{14}$. It is important to identify PCDD/Fs levels in relation to their chemical compositions with respect to the particle size of fly ash.

Over the past two decades, potential release from municipal solid wastes fly ash has caused much public concerns and been widely investigated. This issue is especially important in China since the concept of separation and recycling of refuse is not generally adopted. However, little information is available on physical and chemical properties of fly ash particles as a function of fly ash particle size from a single source to aid in the treatment and utilization, even though attempts have been made to utilized fly ash as composite materials in many fields. Especial attention should be paid not only to prevent environmental pollution, but also to utilize as a resource material. In this regard, the acquaintance of the constitution characteristics of fly ash needs to be acquainted.

The chemical composition and physical structure of fly ash particles can influence the properties and composites of individual fly ash particles. The primary objective of this study is to determine the physical and chemical characteristics of fly ash particles as a function of size. In the work presented here, fly ash was sieved to size classes into five fractions. The size dependent characteristics, including particle size distribution, morphology, mineralogical and chemical composition, leaching behaviour of heavy metals of ash particles, levels of polychlorinated dibenzo- $p$-dioxins and polychlorinated dibenzofurans in individual municipal solid waste fly ash particles were analyzed and evaluated. The quantitative descriptions of the underlying context have been done to provide tools to close the gap between experimental data and theoretical interpretation. This characterization may be used to assess the environmental hazards and reach the goal of zero waste.

\section{EXPERIMENTAL}

Sample acquisition: Fly ash samples were taken from a container filled with accumulated bag filter of Likeng Municipal Waste Incineration Plant. The plant is located in Guangzhou, China. The municipal solid waste incinerator has $2900 \mathrm{t} / \mathrm{d}$ capacities. The colour of fly ash spans the spectrum from light tan to gray black and the moisture content of fly ash is $1.7 \%$. The analysis (\% w/w) was as follows: carbon $5.1 \%$ and oxygen $48.6 \%$. The $\mathrm{pH}$ in water was 11.8 with a liquid to solid ratio 2.5 (w/w). As shown in Table-1, the total metal concentrations in the fly ash were relatively high. The major elements found to be present in fly ash are $\mathrm{Ca}, \mathrm{K}, \mathrm{Na}$, $\mathrm{Si}, \mathrm{Fe}$ and $\mathrm{Mg}$, with mean concentrations of 162.0, 39.4, 30.4, $5.4,9.6,13.1 \mathrm{~g} / \mathrm{kg}$, respectively. The mean concentrations of $\mathrm{Zn}, \mathrm{Cr}$ and $\mathrm{Pb}$ were typically $12.7,5.1$ and $4.9 \mathrm{~g} / \mathrm{kg}$, respectively. Other mean concentrations, $\mathrm{Cu}, \mathrm{Mn}, \mathrm{Ni}$ and $\mathrm{Cd}$ were $1.0,0.5,0.3$ and $0.3 \mathrm{~g} / \mathrm{kg}$, respectively.

Particle size distribution: The particle size distribution of the ash was segregated into different fractions using a shaker fitted with stainless steel mesh screens to particle size classes of $40,80,120,200,400$ meshes. The ash was dried at $105^{\circ} \mathrm{C}$ for $24 \mathrm{~h}$ and then sieved into six different fractions with different dimension ranges: $>375 \mu \mathrm{m}, 187.5-375 \mu \mathrm{m}, 125-187.5$ $\mu \mathrm{m}, 75-125 \mu \mathrm{m}, 37.5-75 \mu \mathrm{m}$ and $<37.5 \mu \mathrm{m}$. Fly ash characteristics were analyzed for each fraction except the one with the largest particle size interval $(>375 \mu \mathrm{m})$.

\begin{tabular}{|c|c|c|c|c|}
\hline \multicolumn{5}{|c|}{$\begin{array}{c}\text { TABLE-1 } \\
\text { CHARACTERIZATION OF FLY ASH }\end{array}$} \\
\hline \multicolumn{2}{|l|}{ Parameters } & \multicolumn{3}{|c|}{ Parameters } \\
\hline $\mathrm{pH}$ & 11.8 & $\begin{array}{l}\text { Metal total } \\
\text { content }(\mathrm{g} / \mathrm{kg})\end{array}$ & & $\begin{array}{c}\text { Leachate } \\
(\mathrm{mg} / \mathrm{L})\end{array}$ \\
\hline Moisture (\%) & 1.7 & $\mathrm{Ca}$ & 162 & \\
\hline $\mathrm{S}_{\mathrm{BET}}\left(\mathrm{m}^{2} / \mathrm{g}\right)$ & 3.7 & $\mathrm{~K}$ & 39.4 & \\
\hline $\begin{array}{l}\text { Chemical compositions } \\
(\%)\end{array}$ & & $\mathrm{Na}$ & 30.4 & \\
\hline $\mathrm{CaO}$ & 33.4 & $\mathrm{Mg}$ & 13.1 & \\
\hline $\mathrm{SiO}_{2}$ & 7.9 & $\mathrm{Fe}$ & 9.6 & \\
\hline $\mathrm{SO}_{3}$ & 6.2 & $\mathrm{Si}$ & 5.4 & \\
\hline $\mathrm{K}_{2} \mathrm{O}$ & 5.5 & $\mathrm{Ba}$ & 1.32 & \\
\hline $\mathrm{Na}_{2} \mathrm{O}$ & 4.9 & $\mathrm{Mn}$ & 0.45 & \\
\hline $\mathrm{Al}_{2} \mathrm{O}_{3}$ & 3.1 & Sn & 0.08 & \\
\hline $\mathrm{MgO}$ & 1.6 & $\mathrm{Al}$ & 0.05 & \\
\hline $\mathrm{Fe}_{2} \mathrm{O}_{3}$ & 1.5 & As & 0.02 & \\
\hline Basicity (as $\mathrm{CaO} / \mathrm{SiO}_{2}$ ) & 4.3 & $\mathrm{Cu}$ & 1.0 & 0.9 \\
\hline Anion content $(\mathrm{g} / \mathrm{kg})$ & & $\mathrm{Zn}$ & 12.7 & 7.1 \\
\hline $\mathrm{SO}_{4}^{2-}$ & 150.0 & $\mathrm{Ni}$ & 0.3 & 0.9 \\
\hline $\mathrm{Cl}^{-}$ & 9.3 & $\mathrm{Cr}$ & 5.1 & 7.4 \\
\hline $\begin{array}{l}\text { Elemental } \\
\text { compositions (wt.\%) }\end{array}$ & & $\mathrm{Pb}$ & 4.9 & 70.5 \\
\hline $\mathrm{C}$ & 48.6 & $\mathrm{Cd}$ & 0.3 & 0.06 \\
\hline $\mathrm{O}$ & 5.1 & & & \\
\hline
\end{tabular}

The morphology of fly ash was observed using a scanning electron microscopy (SEM, Hitachi S-3000N) equipped with a Quantax SDD EDS (Bruker, resolution $123 \mathrm{eV}$, Germany). This allowed the identification of the morphology of the particles, their size and semi-qualitative chemical composition. Moreover, the crystalline minerals present in the ash were identified using X-ray diffraction (XRD, Bruker $\mathrm{D}_{8}$-advance diffractometer) with $\mathrm{CuK}_{\alpha}$ radiation at $40 \mathrm{kV}$ and $40 \mathrm{~mA}$ settings in the $2 \theta$ range from 5o to $90^{\circ}$. Diffraction patterns were manually analyzed utilizing the joint committee on powder diffraction standards (JCPDS). Nitrogen absorption-desorption isotherms were obtained at $77 \mathrm{~K}$ in a quantachrome autosorb 6 apparatus ${ }^{15}$. The functional groups of fly ash were tested by the technology of fourier transform infrared spectrometry (FTIR) (Nicolet Nexus670, USA) in the wave numbers of 4000$400 \mathrm{~cm}^{-1}$.

The volume percentage of crystalline phases present in fly ash from a given source as a function of particle size was determined using XRD analysis.

The chemical compositions of ash were analyzed with X-ray fluorescence using a Philips PW-2400 analyzer and the quantitative method was Pellet and Uni Quant.

The metal contents were classified and fly ash was digested and analyzed according to EPA Method $3050 \mathrm{~B}^{16}$. A $1 \mathrm{~g}$ dried ash sample was obtained using microwave oven and digested with an acidic solution of $\mathrm{HNO}_{3} / \mathrm{HCl} / \mathrm{H}_{2} \mathrm{O}_{2}$. The solution was diluted with $50 \mathrm{~mL}$ of distilled water. The major cations $\mathrm{K}, \mathrm{Na}, \mathrm{Ca}, \mathrm{Mg}, \mathrm{Cu}, \mathrm{Fe}, \mathrm{Zn}, \mathrm{Ni}, \mathrm{Cr}, \mathrm{Pb}, \mathrm{Cd}$ and $\mathrm{Mn}$ were analyzed under internal laboratory standards analytical conditions using a flame atomic absorption spectrophotometer 
TABLE-2

PHYSICAL CHARACTERISTICS OF FLY ASHES WITH VARIOUS PARTICLE SIZE INTERVAL

\begin{tabular}{lccccc}
\hline Particle size interval & $187.5-375 \mu \mathrm{m}$ & $125-187.5 \mu \mathrm{m}$ & $75-125 \mu \mathrm{m}$ & $37.5-75 \mu \mathrm{m}$ & $<37.5 \mu \mathrm{m}$ \\
\hline Colour & Light $\tan$ & Tan & Gray black & Gray black & Gray black \\
Moisture content $(\%)$ & 0.78 & 0.62 & 1.76 & 1.72 & 1.92 \\
$\mathrm{~S}_{\text {BET }}\left(\mathrm{m}^{2} / \mathrm{g}\right)$ & 1.89 & 2.44 & 4.46 & 5.17 & 5.12 \\
Adsorption average pore diameter $(\mathrm{nm})$ & 46.43 & 32.56 & 26.15 & 29.07 & 30.62 \\
\hline
\end{tabular}

(FAAS, Z-8270 Hitachi, Japan). The concentrations of Si, Al and $\mathrm{SO}_{4}{ }^{2-}$ were determined using spectrophotometer (Unico 2800A, China), the concentrations of $\mathrm{Cl}^{-}$was detected using potentiometric titration (SCHOTT TitroLine Easy, Germany). Following standard materials were used for quality control of instrumental analyses: IRMM standard reference materials BCR-714 (wastewater influent) and BCR-713 (wastewater effluent) for inorganic analytes in samples.

pH-Dependent leaching tests: $10 \mathrm{~g}$ of a sample were put into a $250 \mathrm{~mL}$ conical flask with $100 \mathrm{~mL}$ of distilled water. After $18 \mathrm{~h}$ stirring, the solution was filtrated and $5 \mathrm{M} \mathrm{HCl}$ solution was added. The change of $\mathrm{pH}$ was recorded.

Polychlorinated dibenzo- $p$-dioxins and polychlorinated dibenzofurans analysis: Sample preparation for the analysis of PCDD/Fs was accomplished according to the US EPA method 1613. About $10 \mathrm{~g}$ of each dried fly ash fraction collected was transferred to glass Soxhlet thimbles, spiked with a mixture ${ }^{13} \mathrm{C}_{12}$-labeled PCDD/Fs internal standard and extracted for $24 \mathrm{~h}$ with $250 \mathrm{~mL}$ toluene. The toluene-extract was then concentrated to approximately $10 \mathrm{~mL}$ by a rotary evaporator prior to the cleanup process. After the internal standards were spiked, 2 L carrier solution was extracted with toluene to check the dissolved dioxins. The extracts were firstly washed with $\mathrm{H}_{2} \mathrm{SO}_{4}$ until colourless, subsequently hexane followed by a water rinse were used to neutralize. Sample cleanup was carried out with multi-silica gel column and activated acidic alumina column, respectively. After cleanup the extract was concentrated again then transferred to a vial. Before mass analysis, ${ }^{13} \mathrm{C}_{12}$-labeled PCDD/Fs-recovery standards were added. The size dependent levels of polychlorinated dibenzo- $p$-dioxins and polychlorinated dibenzofurans contained in fly ash particle from a municipal solid waste incinerator were characterized by high resolution gas chromatography/high resolution mass spectrometry (HRGC/HRMS).

Leaching test of heavy metal: The leaching test of ash was carried out according to the Chinese standard testing method for solid waste. The solid weight and distilled water volume ratio used in Chinese standard leaching test was 1:20 $(\mathrm{W}: \mathrm{V})$, leaching time was $18 \mathrm{~h}$ and it was agitated horizontally with $200 \mathrm{rpm}$. The leachate was filtered with $0.45 \mu \mathrm{m}$ glass fiber filter. The filtered leachate was digested and the heavy metals including $\mathrm{Cu}, \mathrm{Zn}, \mathrm{Pb}, \mathrm{Cd}$, $\mathrm{Ni}$ and $\mathrm{Mn}$ were analyzed.

\section{RESULTS AND DISCUSSION}

Particle size distribution: The size distributions of particle mass in the fly ash are illustrated in Fig. 1, which showed unimodal size distributions. There was a broad size distribution of fly ash. The highest peak was located at the particle size range between 37.5 and $75 \mu \mathrm{m}$. Over half of the mass percentages of fly ashes have particle sizes less than $125 \mu \mathrm{m}$ for all incinerators. The cumulative mass fractions in the particle size range below 75,125 and $187.5 \mu \mathrm{m}$ in sequence, were 72.2 , 82.4 and $91.4 \%$, respectively. The fly ash samples sized lower $37.5 \mu \mathrm{m}$ were in a fine powder form.

Size distributions of fly ash particles sampled from various areas and incinerators are not quite similar. The dominant particle size are comparable to those obtained by Chang and Chung $^{11}$, but are higher than those from a hazardous waste incinerator obtained by Cobo et al. ${ }^{15}$.

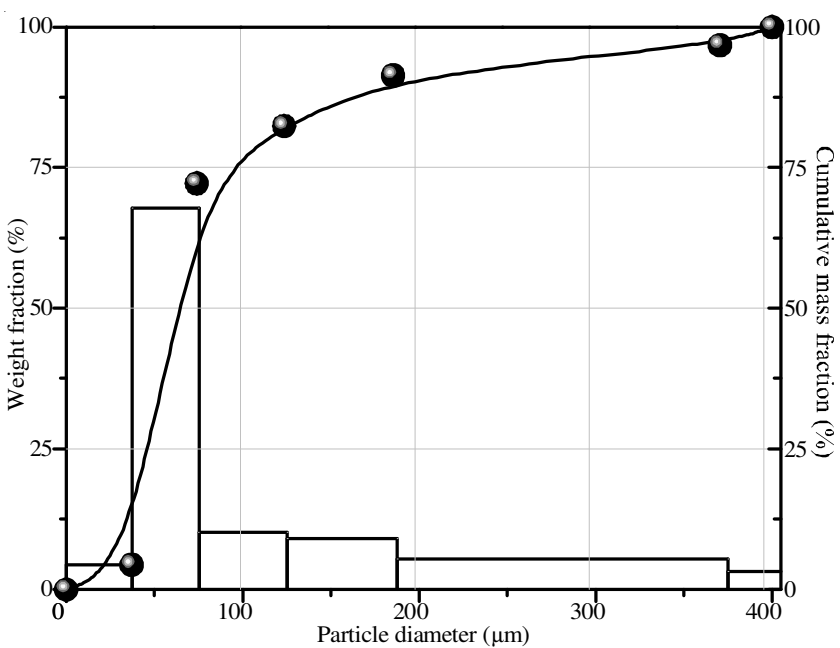

Fig. 1. Weight fraction and cumulative mass fraction for various particle size distribution of fly ash

Surface characteristics: As demonstrated in Table-2 that the specific surface of fly ashes with size lower $75 \mu \mathrm{m}$ were about 3 times as large as that of fly ash with size $>187.5 \mu \mathrm{m}$. Knowledge of the heavy metals content within ash particle size fractions is important for management approaches. The surface area of each particle size range was also an important factor for heavy metal leaching because an increased amount of surface area is available for extraction as the particle size decreased ${ }^{17}$. The BET surface area of fly ash samples in different particle size interval were in a range from 1.89 to 5.17 $\mathrm{m}^{2} / \mathrm{g}$, highest for interval $37.5-75 \mu \mathrm{m}$ and lowest for sample sized higher than $187.5 \mu \mathrm{m}$. There was not significant change of surface area while the particle diameter lower than $75 \mu \mathrm{m}$. The largest adsorption average pore diameter for 187.5-375 $\mu \mathrm{m}$ interval accords with the profile achieved by SEM that sample with the diameter in the interval 187.5-375 are more uniform distribution of more concaves.

Chemical compositions: Chemical compositions of fly ash and the basicity of ash achieved by XRF analysis are given in Table-3. The quantity of oxide material is estimated with the total amount of analyzed element and basicity of ash calculated from the ratio of $\mathrm{CaO}$ and $\mathrm{SiO}_{2}$. Typically, the constituents in the form of compounds are mainly mixtures of sulfates, oxides and silicates. All fly ash samples exhibited similar 
TABLE-3

XRF ANALYSIS OF FLY ASH SAMPLES (UNIT: DRY wt.\%)

\begin{tabular}{|c|c|c|c|c|c|c|c|}
\hline & Raw fly ash & $1 \#>375 \mu \mathrm{m}$ & $2 \# 187.5-375 \mu \mathrm{m}$ & $3 \# 125-187.5 \mu \mathrm{m}$ & $4 \# 75-125 \mu \mathrm{m}$ & $5 \# 37.5-75 \mu \mathrm{m}$ & $6 \#<37.5 \mu \mathrm{m}$ \\
\hline $\mathrm{ZrO}_{2}$ & 0.02 & 0.02 & 0.04 & 0.03 & 0.02 & 0.01 & 0.01 \\
\hline $\mathrm{ZnO}$ & 0.61 & 0.61 & 0.57 & 0.51 & 0.57 & 0.81 & 0.94 \\
\hline $\mathrm{TiO}_{2}$ & 0.67 & 0.98 & 1.38 & 1.26 & 0.73 & 0.49 & 0.43 \\
\hline $\mathrm{SrO}$ & 0.03 & 0.04 & 0.04 & 0.03 & 0.03 & 0.03 & 0.03 \\
\hline $\mathrm{SnO}_{2}$ & 0.05 & 0.06 & 0.04 & 0.03 & 0.05 & 0.06 & 0.09 \\
\hline $\mathrm{SiO}_{2}$ & 7.85 & 12.27 & 27.65 & 21.77 & 8.38 & 6.95 & 5.19 \\
\hline $\mathrm{Sb}_{2} \mathrm{O}_{3}$ & 0.04 & 0.04 & 0.03 & 0.02 & 0.04 & 0.04 & 0.06 \\
\hline $\mathrm{SO}_{3}$ & 6.21 & 8.23 & 6.29 & 7.58 & 7.22 & 6.31 & 5.95 \\
\hline $\mathrm{Rb}_{2} \mathrm{O}$ & 0.09 & 0.04 & 0.02 & 0.01 & 0.05 & 0.07 & 0.06 \\
\hline $\mathrm{PbO}$ & 0.04 & 0.05 & 0.04 & 0.03 & 0.05 & 0.13 & 0.27 \\
\hline $\mathrm{P}_{2} \mathrm{O}_{5}$ & 0.74 & 1.03 & 1.77 & 1.68 & 0.88 & 0.57 & 0.51 \\
\hline $\mathrm{NiO}$ & 0.01 & 0.01 & 0.01 & 0.01 & 0.01 & 0.01 & 0.01 \\
\hline $\mathrm{Na}_{2} \mathrm{O}$ & 4.87 & 4.74 & 3.86 & 3.48 & 7.21 & 3.03 & 1.84 \\
\hline $\mathrm{MnO}$ & 0.06 & 0.10 & 0.08 & 0.08 & 0.07 & 0.05 & 0.04 \\
\hline $\mathrm{MgO}$ & 1.64 & 2.25 & 2.39 & 2.48 & 1.70 & 1.33 & 1.31 \\
\hline $\mathrm{K}_{2} \mathrm{O}$ & 5.51 & 3.90 & 3.14 & 2.50 & 6.04 & 5.91 & 12.20 \\
\hline $\mathrm{Fe}_{2} \mathrm{O}_{3}$ & 1.50 & 1.98 & 3.29 & 3.10 & 1.60 & 1.21 & 1.02 \\
\hline $\mathrm{F}$ & 0.10 & 0.07 & 0.06 & & 0.10 & 0.09 & 0.07 \\
\hline $\mathrm{CuO}$ & 0.07 & 0.06 & 0.05 & 0.03 & 0.06 & 0.08 & 0.09 \\
\hline $\mathrm{Cr}_{2} \mathrm{O}_{3}$ & 0.37 & 0.47 & 0.45 & 0.42 & 0.40 & 0.35 & 0.37 \\
\hline $\mathrm{CdO}$ & 0.01 & 0.01 & 0.00 & 0.00 & 0.01 & 0.01 & 0.02 \\
\hline $\mathrm{CaO}$ & 33.41 & 33.21 & 25.09 & 24.95 & 31.63 & 35.66 & 30.59 \\
\hline $\mathrm{Br}$ & 0.16 & 0.11 & 0.07 & 0.05 & 0.13 & 0.21 & 0.20 \\
\hline $\mathrm{Co}_{3} \mathrm{O}_{4}$ & 0.01 & 0.01 & 0.01 & 0.01 & & & \\
\hline $\mathrm{BaO}$ & 0.21 & 0.16 & 0.21 & 0.22 & 0.15 & 0.13 & 0.12 \\
\hline $\mathrm{As}_{2} \mathrm{O}_{3}$ & 0.01 & & & & & & 0.04 \\
\hline $\mathrm{Al}_{2} \mathrm{O}_{3}$ & 3.10 & 4.87 & 9.24 & 8.29 & 3.54 & 2.55 & 1.93 \\
\hline $\mathrm{MoO}_{3}$ & & 0.00 & 0.00 & 0.00 & & & 0.00 \\
\hline $\mathrm{Bi}_{2} \mathrm{O}_{3}$ & & & & & & & 0.01 \\
\hline $\mathrm{Cl}$ & 21.63 & 14.03 & 6.64 & 5.78 & 18.70 & 24.15 & 26.60 \\
\hline Basicity & 4.26 & 2.71 & 0.91 & 1.15 & 3.77 & 5.13 & 5.90 \\
\hline
\end{tabular}

composition and the major constituents are $\mathrm{SiO}_{2}, \mathrm{SO}_{3}, \mathrm{CaO}$, $\mathrm{K}_{2} \mathrm{O}, \mathrm{Na}_{2} \mathrm{O}, \mathrm{Al}_{2} \mathrm{O}_{3}$ and $\mathrm{NaCl} . \mathrm{SiO}_{2}, \mathrm{Fe}_{2} \mathrm{O}_{3}$ and $\mathrm{Al}_{2} \mathrm{O}_{3}$ decreased as the particle size decreased but $\mathrm{K}_{2} \mathrm{O}, \mathrm{Cl}$ increased as the particle size decreased. The concentrations of alkali and alkaline earth elements, such as $\mathrm{K}_{2} \mathrm{O}, \mathrm{Na}_{2} \mathrm{O}, \mathrm{CaO}$ and $\mathrm{MgO}$ are higher.

$\mathrm{SiO}_{2}$ was a major compound in fly ash at the particle size ranges the 125-187.5 $\mu \mathrm{m}$ and showed the least amount in the ash with particle size lower than $37.5 \mu \mathrm{m}$. Low proportions of $\mathrm{Si}$ and $\mathrm{Al}$ makes the fly ash structure weak and prone to leaching in contrast with the higher loading of $\mathrm{SiO}_{2}$ and $\mathrm{Al}_{2} \mathrm{O}_{3}$, due to the net structure of $\mathrm{SiO}_{2}$ and $\mathrm{Al}_{2} \mathrm{O}_{3}$ can fix heavy metals to be not extracted easily ${ }^{18}$. The leaching test demonstrated the observation.

The chloride concentrations of the order of 5.78-26.6\% were present in fly ash samples, a sufficient amount to provide anions for most of the heavy metals present in the ash. Only a small amount of $\mathrm{Cl}$ was indicated in fly ash sized ranging $125-$ $187.5 \mu \mathrm{m}$ and a large amount in the ash size $<75 \mu \mathrm{m}$. There were a negative correlation between particle size and chlorine content in the fly ash samples. Stanmore ${ }^{19}$ and Chen et al. ${ }^{20}$ revealed that high chlorine concentration was due to the fact that smaller particles had higher specific surface areas offering more adsorption sites. Fangmark et al..$^{21}$ supported the hypothesis that small fly ash particles with most of the surface area, were the main contributors to the levels of chlorinated aromatic compounds found in flue gases. From these results one could infer that a significant portion of metal and organic chlorides with deposition into small solid particles. Hence, if cement solidification/stabilization process of fly ash is adopted, preliminary washing treatment with water to remove massive soluble chlorides salt should be taken considering fine particle fractions $^{22}$

The concentrations of $\mathrm{K}_{2} \mathrm{O}, \mathrm{Al}_{2} \mathrm{O}_{3}$ were differed by an order of magnitude between these samples. The fractions of $\mathrm{Al}_{2} \mathrm{O}_{3}$ in fly ash particles are shown to be dependent of their size. On the other hand, $\mathrm{CuO}, \mathrm{NiO}, \mathrm{MnO}$ and $\mathrm{CrO}$ showed no difference between various particle intervals. $\mathrm{As}_{2} \mathrm{O}_{3}$ was detected only in the finest particle.

Lime (calcium oxide, $\mathrm{CaO}$ ) was found in almost the same amount in all sized fraction fly ashes, but smaller amount of $\mathrm{CaO}$ in the fly ashes sized $125-187.5 \mu \mathrm{m}$. Most of the metal oxides having low volatility such as $\mathrm{Fe}_{2} \mathrm{O}_{3}$ and $\mathrm{TiO}_{2}$, were found with large amounts in the larger fly ashes with size $>125 \mu \mathrm{m}$. The basicity increased as the particle size of fly ash increased, with the exception of particle size $>375 \mu \mathrm{m}$.

Acid neutralization capacity: The acid neutralization capacity is probably the most relevant fly ash property affecting the $\mathrm{pH}$ of the leachate ${ }^{5}$. Fig. 2 depicts the acid neutralization capacity of fly ash samples. At the beginning of acid addition, the $\mathrm{pH}$ decreases insignificant due to the added acid was consumed to neutralize the dissolving basic metal salts (buffering 
capacity of the fly ash). The added acid gave a logarithmic decrease in the $\mathrm{pH}$ while the amount of basic salts was exhausted and insufficient to neutralize.

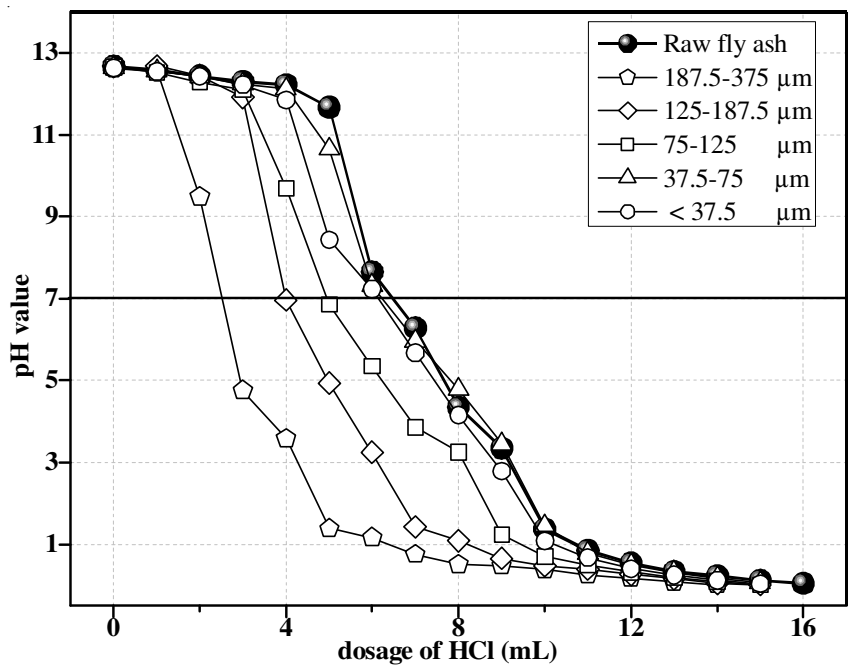

Fig. 2. Acid titration curves of fly ash samples ( $\mathrm{S} / \mathrm{L}=10 \mathrm{~g} / \mathrm{L}$, extraction time $=18 \mathrm{~h})$

The acid neutralization capacities with various particle intervals were remarkably different. The acid neutralization capacity increased with the decrease of particle diameter. Only small amounts of basic metal salts dissolve in sample with particle diameter interval 187.5-375 $\mu \mathrm{m}$, so that $\mathrm{pH}$ decreased significantly. This indicated that fly ash sample sized 187.5$375 \mu \mathrm{m}$ might consist of more rock minerals such as highly polymerized silicates and aluminosilicates that were not easily leached. A highly alkaline conditions exist due to the excessive alkali content of $\mathrm{CaO}$ in lime were injected to neutralize acid gas. A benefit for high $\mathrm{CaO}$ content is that the high acid neutralization capacity against acid rain prevalent in south of China. Moreover, highly alkaline condition has a significant impact on the leaching toxicity of heavy metals.

Morphology of fly ash particles: The morphology of five fly ash samples shown in Fig. 3 demonstrated that fly ash samples were very anomalous in shapes of tablets. Generally, they were irregular amorphous forms and polycrystalline aggregates, regular crystals were rarely observed. The coarse particles with size 187.5-375 $\mu \mathrm{m}$ were mainly composed of more porous particles. The image of fine particle with size < $37.5 \mu \mathrm{m}$ showed a drastically difference from other ash samples with porous network structure. All fly ash samples consisted of amorphous particles. The surface of fly ash with 75-125 $\mu \mathrm{m}$ size produced smoother agglomerations than other samples. Sample with diameter in 187.5-375 $\mu \mathrm{m}$ was more uniform distribution of concaves. Furthermore, three sample with diameter lower than 187.5 had fairly smooth surfaces. The influence of the surface of samples maybe contributed from the complex components that may cause the particles to agglomerate at high temperature during combustion. It was noted that the fine fly ash samples were composed of more tiny irregular amorphous particulates, which showed the structure of fly ash was more complex.

Ramesh and Kozinski ${ }^{23}$ indicated that there were close relation between morphology of fly ash and the leaching
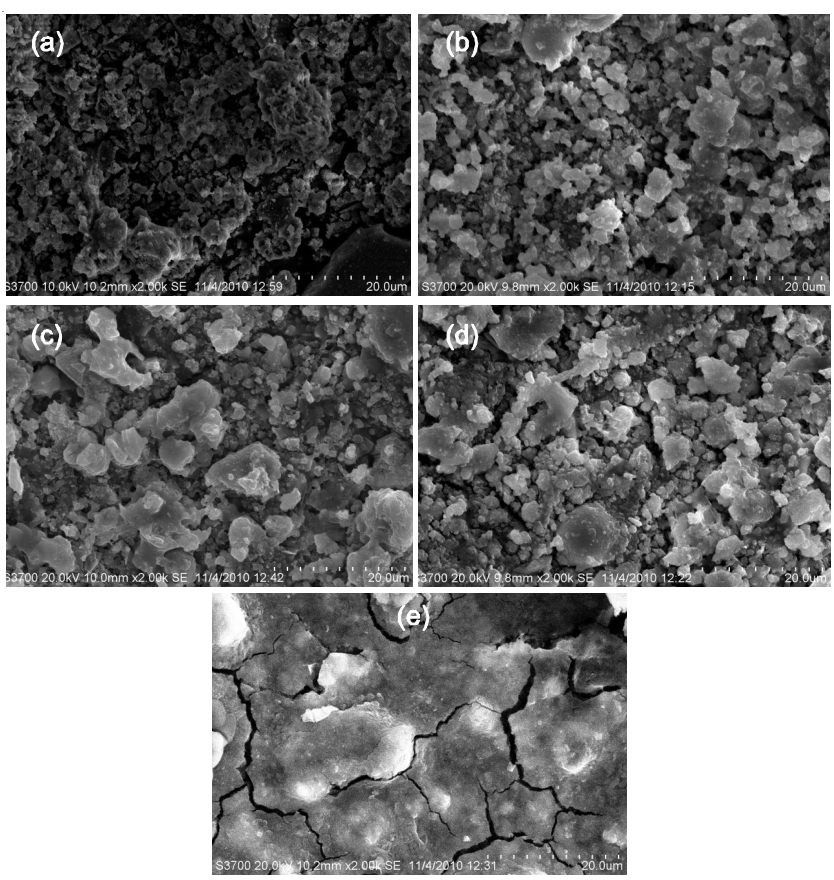

Fig. 3. SEM images of fly ash samples; [(a)187.5-375 $\mu \mathrm{m}$; (b) 125-187.5 $\mu \mathrm{m}$; (c) $75-125 \mu \mathrm{m}$; (d) 37.5-75 $\mu \mathrm{m}$; (e) $37.5-75 \mu \mathrm{m}$ ]

behaviour of metals. Like the fly ash particle with noncontinues, loose, porous and large specific surface area, the leaching solution can easily percolate into the particle and accelerate the solution of the heavy metals.

Typical EDS spectra showing the microchemistry of the fly ash particles of different sizes are also shown in Fig. 4. The main elements detected by EDS in all five samples were $\mathrm{O}, \mathrm{Ca}, \mathrm{Cl}, \mathrm{Zn}$ and $\mathrm{K}$. As previously mentioned, the presence of $\mathrm{O}, \mathrm{Ca}, \mathrm{Si}$ and $\mathrm{Cl}$ might be silicates and alkali metal salt. Determined elements by EDS fit well with the XRF and XRD measurements. It was noted that the highest carbon occurred in the sample with size interval 187.5-375 $\mu \mathrm{m}$. The result demonstrated the observation during segregation that some small black granules left in 80 mesh shaker with size 187.5$375 \mu \mathrm{m}$ were carbon particle. The result was in accord with the observation of Shibaoka ${ }^{24}$ that the carbon content of a fly ash was high, the proportion of coarse size classes was also high.

Additionally, it was unexpected that $\mathrm{Al}$ and $\mathrm{F}$ with 14.2$16.8 \%$ (wt. \%) are significantly enriched in the finest sample with size lower than $37.5 \mu \mathrm{m}$ (wt \% ). The result was in accord with the explanation proposed by Klein et al. ${ }^{25}$ that small particles may be formed either by high-temperature vaporization followed by condensation upon cooling. However, contradictory observation achieved compared with the results observed by Greenberg et $a l .{ }^{26}$ that aluminum form volatile chlorides were not particularly concentrated in fly ash, which indicated complicated metal transport mechanisms. Except for $\mathrm{Al}$ in fly ash with particle size interval lower $37 \mu \mathrm{m}$, the particlemediated behaviour of $\mathrm{Al}, \mathrm{Zn}$ and $\mathrm{K}$ were similar due to their weight percentage of $\mathrm{Zn}, \mathrm{K}$, were similar in each distincted particle size.

XRD mineralogy: The analytical results demonstrate that all samples have highly complex mineralogy. These fly ash samples have the same crystalline components, such as $\mathrm{SiO}_{2}$, 


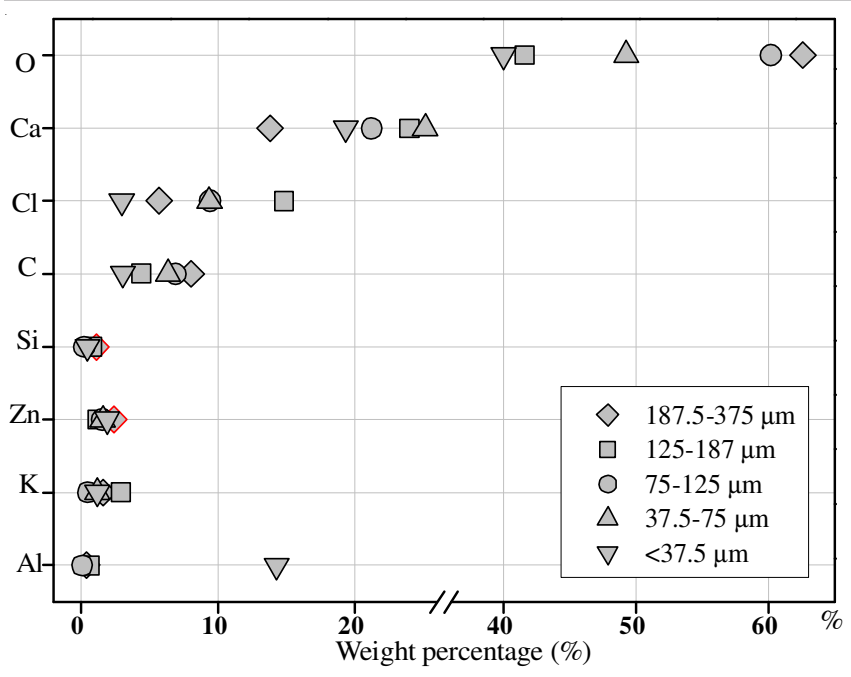

Fig. 4. Main elements detected by EDS in samples

$\mathrm{CaSO}_{4}$ and $\mathrm{CaCO}_{3}$ and fly ashes samples with size lower than $125 \mu \mathrm{m}$ contained more $\mathrm{NaCl}$ and $\mathrm{KCl}$.

It is seen (Fig. 5) that there are not much significant difference for XRD profiles. But coarse samples present higher intensity of diffraction peaks due to the lower crystallinity of coarse fly ash.

The major crystalline phases identified in the interval 187.5-375 $\mu \mathrm{m}$ are $\mathrm{CaSO}_{4}$ and $\mathrm{NaCl}$, which in accordance with previous identification of high $\mathrm{SO}_{3}$ content of fly ash. The mainly crystalline compounds of the fly ash with 187.5-375 $\mu \mathrm{m}$ diameter interval detected include $\mathrm{CaSO}_{4}, \mathrm{NaCl}, \mathrm{KCl}$, $\mathrm{SiO}_{2}{ }^{10}$.

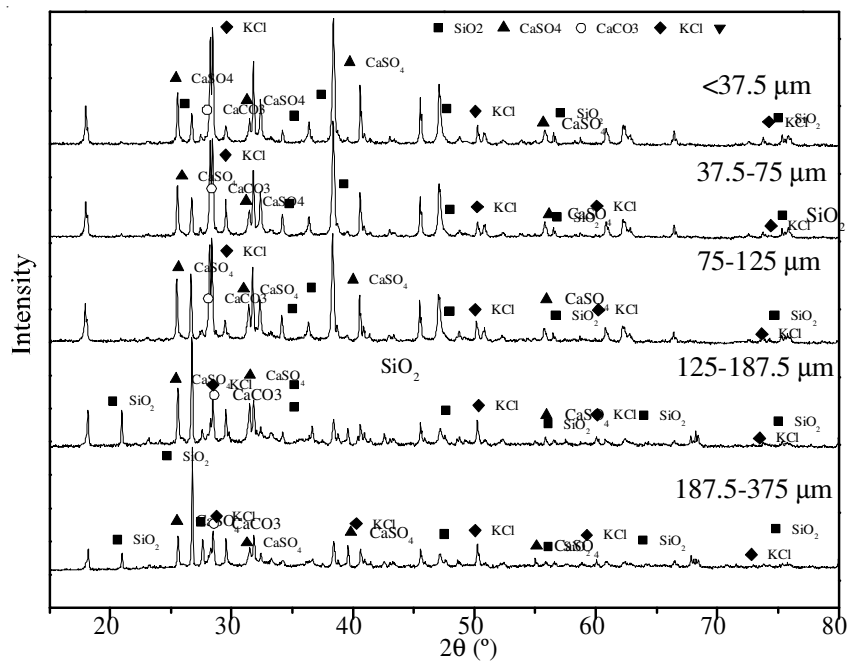

Fig. 5. XRD of the samples

FT-IR: Fig. 6 illustrated the FT-IR transmittance spectra of five samples. All fly ash samples showed strong Si-O bands at $1130-830 \mathrm{~cm}^{-1}$. It was noted that the two main spectral peaks at about 480 and $1110 \mathrm{~cm}^{-1}$, the former has been assigned to $\mathrm{Si}-\mathrm{O}-\mathrm{Si}$ and $\mathrm{O}-\mathrm{Si}-\mathrm{O}$ bending and the latter to $\mathrm{Si}-\mathrm{O}-\mathrm{Si}$ and Al-O-Si asymmetric stretching ${ }^{28}$. In addition, three peaks associated with their Al-Si framework, generally of much lesser intensity, at about 810,750 and $590 \mathrm{~cm}^{-1}$, being attributed to $\mathrm{Si}-\mathrm{O}-\mathrm{Si}$ and Al-O-Si symmetric stretching. The spectral band at about $1435 \mathrm{~cm}^{-1}$ appeared in all samples. This band is characteristic of carbonate asymmetric stretching, suggests the presence of sodium carbonate ${ }^{28}$. The adsorption bands at 1638$595 \mathrm{~cm}^{-1}$ were assigned to $\mathrm{SO}_{3}$ on the samples. The stretching adsorption band of $\mathrm{O}-\mathrm{H}$ in the crystal structure of the adsorbent is observed at $3645 \mathrm{~cm}^{-1}$ assigned to free hydroxyl ${ }^{29}$.

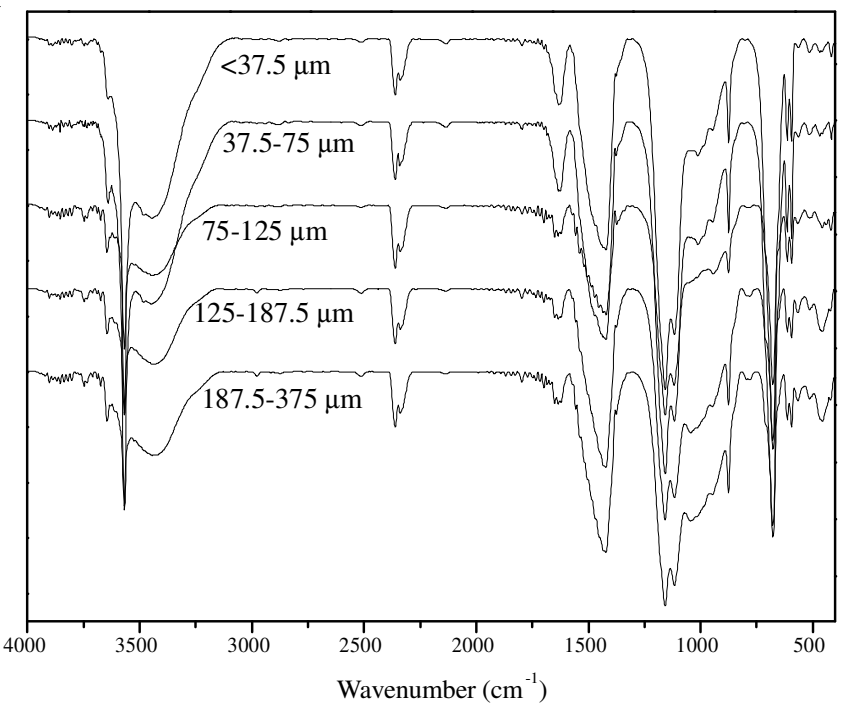

Fig. 6. FTIR of fly ash factions with various particle sizes

PCDD/F: Dioxin contents and 2,3,7,8-T4CDD toxicity equivalency quantities of the samples were summarized in Table-4. The toxicity equivalency quantities was calculated according to 2,3,7,8-T4CDD toxicity equivalency factor. The concentrations of PCDD/Fs homologues measured in each size fraction are listed in Table- 4 and their homologue patterns are compared by normalizing the data to the sum of [PCDDs] + [PCDFs] $)=1$ (Fig. 7). All the particles have larger polychlorinated dibenzo- $p$-dioxins distributions and relatively small in case of polychlorinated dibenzofurans. PCDD/PCDF ratios of five fractions are $>1$. The results indicated that the environment more favoured the formation of polychlorinated dibenzo$p$-dioxins. Further investigation will be conducted to elucidate the phenomenon.

The total PCDD/Fs concentrations for each fraction were from 5.17 to $91.16 \mathrm{ng} / \mathrm{g}$ (0.001-1.23 ng I-TEQ/g-fraction), showing a wide range for different fly ash sizes. The toxicity equivalency quantities values of PCDD/Fs in with particle diameter lower than $75 \mu \mathrm{m}$ (1.23-6.68 ng I-TEQ/g) exceeded $1 \mathrm{ng}$ I-TEQ/g, which was a residential soil criteria for some countries, such as Germany and United states. As shown, the smaller the particle diameter, the larger PCDD/Fs concentrations. The fractions with particle diameter $<37.5 \mu \mathrm{m}$ had the largest concentrations of about $91.16 \mathrm{ng} / \mathrm{g}$. This result strongly suggested that PCDD/Fs were preferentially carried on smaller particles. A similar trend had been reported by Shin and Chang ${ }^{30}$, Chang et al. ${ }^{11}$ and Moon et al. ${ }^{12}$ that the concentration of PCDD/Fs increased with the decrease of particle size of fly ash. Moreover, the concentrations of higher-chlorinated congeners of dioxins were remarkably higher than those of lower-chlorinated congeners. The toxic effect of dioxins in the fly ash was mainly caused by polychlorinated dibenzofurans. 
TABLE-4

PCDD/Fs CONCENTRATIONS IN VARIOUS FLY ASH FRACTIONS (ng/g)

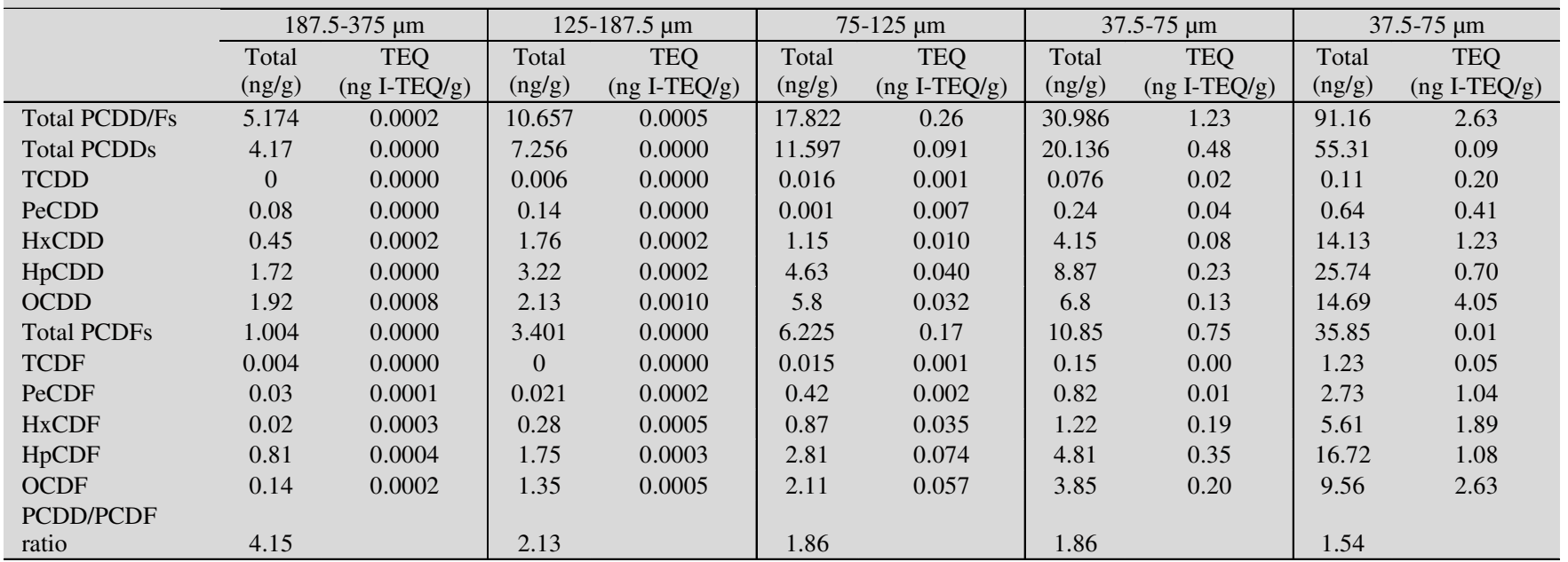

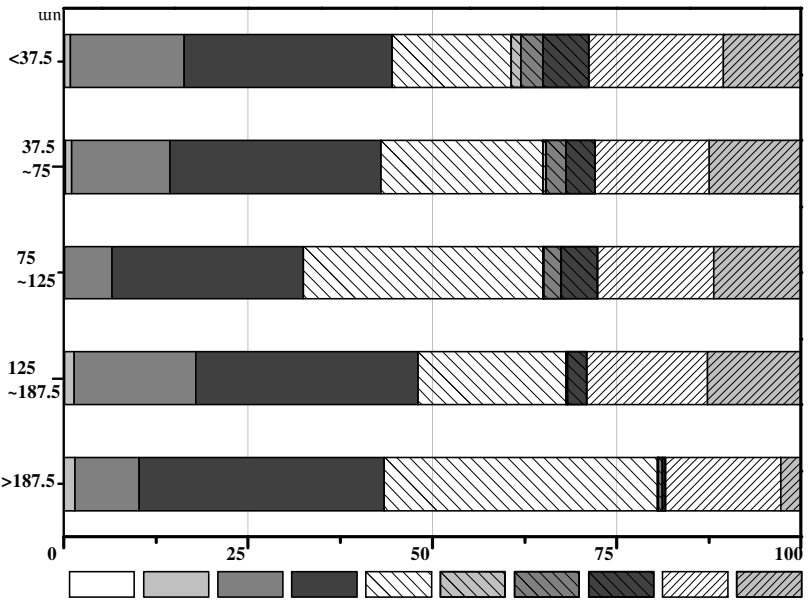

TCDD PeCDD HxCDD HpCDD OCDD TCDF PeCDF HxCDF HpCDF OCDF

Fig. 7. Normalized homologue profiles of total PCDD/Fs compared for each different size fraction.

Leaching behaviour of heavy metal from ashes: In this section, six toxic metals were selected from the list of identification standards for hazardous materials-identification for extraction toxitity ${ }^{31}$ GB 5085.3-2007) to analyze. It shows that the contents of $\mathrm{Zn}, \mathrm{Pb}, \mathrm{Cr}$ and $\mathrm{Cu}$ are high in fly ash. Especially, the content of $\mathrm{Zn}$ reaches up to $6507.5-13260 \mathrm{mg} / \mathrm{kg}$ in samples. The volatile heavy metals $\mathrm{Cu}, \mathrm{Zn}, \mathrm{Pb}$ and $\mathrm{Cd}$ present increased concentration trends with decreasing particle size, in contrast with $\mathrm{Ni}$ and $\mathrm{Cr}$ decreasing with the particle size decreased. The highest concentrations of $\mathrm{Cu}, \mathrm{Zn}, \mathrm{Pb}$ and $\mathrm{Cd}$ were observed at the particle size lower $37.5 \mu \mathrm{m}$ with large specific surface area. According to previous investigations, the vaporized metals were condensed and aggregated on the surface of find particles due to the temperature in flue gas cooling system $^{32}$ and silicalike lithophilic elements $\mathrm{Cr}$ and $\mathrm{Ni}$ were not enriched in fly $\mathrm{ash}^{8}$. Moreover, $\mathrm{Cu}$ occurs in fly ash with a relatively high boiling point since it may partially convert into $\mathrm{CuCl}_{2}$ during the incineration with $\mathrm{Cl}$ and then partly enters into fly $\operatorname{ash}^{33}$. Chromium was less affected by temperature because it is known to convert into $\mathrm{CrO}_{3}$, which is a relatively more stable compound in high temperature oxidation conditions ${ }^{18}$.

In the results of analysis for content and leaching behaviour of metals $\mathrm{Cu}, \mathrm{Zn}$ and $\mathrm{Ni}$, fly ashes with various particles showed low leaching ratio of these metals though high concentrations occurred in. These results were worthwhile to show the irregularity of metals leaching characteristics though it was very difficult to explain all the leaching characteristics of heterogeneous ash from municipal solid wastes because the leaching of ashes depends on many physicochemical influences ${ }^{18}$. The metal Ni showed stable and almost completely remained in fly ash.

Leaching test showed that leaching concentrations of $\mathrm{Zn}$, $\mathrm{Cr}$ and $\mathrm{Pb}$ exceeded the limit value in "Identification Standard of Hazardous Waste-Identification of Leaching Toxicity" (GB5085.3-2007), whereas metals concentrations of $\mathrm{Cu}, \mathrm{Cd}$ and Ni fell within upper limits of the standard. The leachated concentrations of $\mathrm{Pb}$ in fly ash samples are 2-16 times higher than the regulatory level, especially in fine particles with size $<125 \mu \mathrm{m}$. Therefore, the fly ashes should be treated prior to enter in hazardous waste landfill sites.

Additionally, the leaching ratios of metals in finer ash were higher than those in coarse fly ashes with higher amount of $\mathrm{SiO}_{2}$, because metals fixed in the $\mathrm{SiO}_{2}$ net structure were more difficult to be extracted ${ }^{34}$. On the other hand, Cd was not detected in all leachates because they are primarily carried over by combustion vapour. As a portion of fly ash, these large amounts of non-volatile substances were characterized of lower leaching concentrations ${ }^{35}$.

The behaviours of metals found in this study are close to results of Jiang et al. ${ }^{35}$ that the content of heavy metals and leaching toxicity maybe have no convincing correlation, different leaching results were observed from various samples with different sizes. Some difference would be due to different waste composition, conditions and incineration processes. In addition, the result that the particle size effect on the leaching behaviour of tested metals was insignificant while the size lower than 75 $\mu \mathrm{m}$ maybe relevant to the observation reported earlier that the surface area varied insignificantly with the particle size decreased lower than $75 \mu \mathrm{m}$. Therefore, knowledge of heavy metals content within ash particle size fractions is important for management approaches.

It was noted that the findings that leaching concentrations for the related metals were not significantly affected by changes in the particle size lower than $75 \mu \mathrm{m}$, was in accord with the 


\begin{tabular}{|c|c|c|c|c|c|c|c|}
\hline \multicolumn{8}{|c|}{$\begin{array}{r}\text { TABLE-5 } \\
\text { TOTAL CONCENTRATIONS AND LEACHING CON }\end{array}$} \\
\hline & $1 \#>375 \mu \mathrm{m}$ & 2\# 187.5-375 $\mu \mathrm{m}$ & 3\# $125-187.5 \mu \mathrm{m}$ & 4\# 75-125 $\mu \mathrm{m}$ & $5 \# 37.5-75 \mu \mathrm{m}$ & $6 \#<37.5 \mu \mathrm{m}$ & Limit $(\mathrm{mg} / \mathrm{L})$ \\
\hline \multicolumn{8}{|c|}{ Total $(\mathrm{mg} / \mathrm{kg})$} \\
\hline $\mathrm{Cu}$ & 699.5 & 668.5 & 572.0 & 860.0 & 994.5 & 1225.0 & \\
\hline $\mathrm{Zn}$ & 8252.5 & 6680.0 & 6507.5 & 10702.5 & 11210.0 & 13260.0 & \\
\hline $\mathrm{Ni}$ & 116.5 & 144.3 & 188.3 & 112.0 & 120.0 & 88.0 & \\
\hline $\mathrm{Cr}$ & 1831.5 & 1644.0 & 2431.0 & 1506.0 & 1489.5 & 1150.5 & \\
\hline $\mathrm{Pb}$ & 2014.0 & 2016.0 & 1618.5 & 3205.0 & 4159.5 & 4814.0 & \\
\hline $\mathrm{Cd}$ & 208.4 & 135.5 & 86.3 & 258.9 & 335.2 & 428.5 & \\
\hline No. & 1 & 2 & 3 & 4 & 5 & 6 & \\
\hline \multicolumn{8}{|c|}{ Leachate $(\mathrm{mg} / \mathrm{L})$} \\
\hline $\mathrm{Cu}$ & 0.2 & 0.3 & 0.2 & 0.4 & 0.5 & 0.7 & 100 \\
\hline $\mathrm{Zn}$ & 2.3 & 3.2 & 1.8 & 4.1 & 5.4 & 6.9 & 100 \\
\hline $\mathrm{Ni}$ & 0.2 & 0.3 & 0.1 & 0.1 & ND & 0.0 & 5 \\
\hline $\mathrm{Cr}$ & 6.7 & 9.6 & 11.0 & 6.1 & 4.9 & 5.6 & 15 \\
\hline $\mathrm{Pb}$ & 19.5 & 18.1 & 9.0 & 43.5 & 64.7 & 81.1 & 5 \\
\hline $\mathrm{Cd}$ & ND & ND & ND & ND & ND & ND & 1 \\
\hline No. & 1 & 2 & 3 & 4 & 5 & 6 & \\
\hline \multicolumn{8}{|c|}{ Ratio (\%) } \\
\hline $\mathrm{Cu}$ & 0.7 & 0.8 & 0.8 & 0.8 & 1.0 & 1.2 & \\
\hline $\mathrm{Zn}$ & 0.6 & 1.0 & 0.5 & 0.8 & 1.0 & 1.0 & \\
\hline $\mathrm{Ni}$ & 3.5 & 4.5 & 0.6 & 1.1 & 0.0 & 0.9 & \\
\hline $\mathrm{Cr}$ & 7.3 & 11.7 & 9.0 & 8.0 & 6.6 & 9.6 & \\
\hline $\mathrm{Pb}$ & 19.3 & 17.9 & 11.2 & 27.1 & 31.1 & 33.7 & \\
\hline $\mathrm{Cd}$ & 0.0 & 0.0 & 0.0 & 0.0 & 0.0 & 0.0 & \\
\hline
\end{tabular}

earlier observation ${ }^{17}$ that not significant surface area change when the particle diameter lower than $75 \mu \mathrm{m}$.

\section{Conclusion}

The size dependent characterization of fly ash from municipal solid waste incinerators were investigated with the fly ash segregated into five fractions. There were inverse relationships of the surface area, acid neutralization capacities, leaching behaviour of heavy metals, levels of polychlorinated dibenzo- $p$-dioxins and polychlorinated dibenzofurans with particle size. The results indicated that the characterization of municipal solid waste incinerator fly ash had the potential size dependent information of particulate materials in relation to their production processes, chemical compositions, environmental fates and other factors. The results were due to transportation and mixing system inside incinerators. The finer particle size of fly ash, the higher environmental risk occurs.

\section{ACKNOWLEDGEMENTS}

The authors gratefully acknowledged the financial support from National Environment Protection Program for Commonweal Industry of China (No. 201009063, 2011467024, 201209022, No. ZX-200809-06 and ZX-201106-089).

\section{REFERENCES}

1. NBSC, China Statistical Yearbook, China Statistics Press, Beijing (2008).

2. Q. Wang, J.H. Yan, Y. Chi, X.D. Li and S.Y. Lu, Chemosphere, 78, 626 (2010).

3. J.L. Domingo, S. Granero and M. Schuhmacher, Chemosphere, 43, 517 (2001).

4. J. Yang, J. Wen, Q.C. Liu, G.F. Wu, L. Liu and Y.P. Lan, Asian J. Chem., 25, 157 (2013)

5. L.K. Thetwar, N.C. Desmukh, A.K. Jangde, G.K. Keshkar, N.K. Tripathi, S. Sharma and R.C. Tandon, Asian J. Chem., 19, 3515 (2007).
6. R.D. Li, L. Wang, T.H. Yang and B. Raninger, Waste Manage., 27, 1383 (2007).

7. H. Avci, I. Akdeniz and M. Yaman, Asian J. Chem., 20, 2827 (2008).

8. A. Kida, Y. Noma and T. Imada, Waste Manage., 16, 527 (1996).

9. K. Nakamura, S. Kinoshita and H. Takatsuki, Waste Manage., 16, 509 (1996).

10. F.Y. Chang and M.Y. Wey, J. Hazard. Mater., 138, 594 (2006).

11. M.-B. Chang and Y.-T. Chung, Chemosphere, 36, 1959 (1998).

12. M.H. Moon, D.J. Kang, H.B. Lim, J.O.E. Oh and Y.S. Chang, Environ. Sci. Technol., 36, 4416 (2002).

13. H. Matzing, W. Baumann, B. Becker, K. Jay, H.R. Paur and H. Seifert, Chemosphere, 42, 803 (2001).

14. O. Hutzinger, M.J. Blumich, M.V.D. Berg and K. Olie, Chemosphere, 14, 581 (1985).

15. M. Cobo, A. Galvez, J.A. Conesa and C.M. de Correa, J. Hazard. Mater., 168, 1223 (2009)

16. E.M.L. Lorentzen and H.M. "Skip" Kingston, Anal. Chem., 68, 4316 (1996).

17. K.-Y. Chiang, J.-C. Jih and M.-D. Chien, Hydrometallurgy, 93, 16 (2008).

18. G.J. Song, K.H. Kim, Y.C. Seo and S.C. Kim, Waste Manage., 24, 99 (2004).

19. B.R. Stanmore, Flame, 136, 398 (2004)

20. C.K. Chen, C.E. Lin, L.C. Wang and G.P. Chang-Chien, Chemosphere, 65, 514 (2006).

21. I. Fängmark, B. Strömberg, N. Berge and C. Rappe, Waste Manage. Res., 13, 259 (1995).

22. C.C. Goh, K.Y. Show and H.K. Cheong, J. Mater. Civil Engg., 15, 513 (2003).

23. A. Ramesh and J.A. Kozinski, Environ. Poll., 111, 255 (2001).

24. M. Shibaoka, Fuel, 65, 449 (1986).

25. D.H. Klein, A.W. Andren, J.A. Carter, J.F. Emery, C. Feldman, W. Fulkerson, W.S. Lyon, J.C. Ogle, Y. Talmi, R.I. Van Hook and N. Bolton, Environ. Sci. Technol., 9, 973 (1975).

26. R.R. Greenberg, W.H. Zoller and G.E. Gordon, Environ. Sci. Technol., 12, 566 (1978)

27. T. Matsunaga, J.K. Kim, S. Hardcastle and P.K. Rohatgi, Mater. Sci. Engg. A, 325, 333 (2002).

28. E. Álvarez-Ayuso, X. Querol, F. Plana, A. Alastuey, N. Moreno, M. Izquierdo, O. Font, T. Moreno, S. Diez, E. Vázquez and M. Barra, J. Hazard. Mater., 154, 175 (2008). 
29. N. Dizge, C. Aydiner, E. Demirbas, M. Kobya and S. Kara, J. Hazard. Mater., 150, 737 (2008).

30. K.-J. Shin and Y.-S. Chang, Chemosphere, 38, 2655 (1999).

31. GB5085.3-2007, Identification Standard of Hazardous Waste-identification of Leaching Toxicity, in China.

32. M.A. Fernhdez, L. Marfiner, M. Segarra, J.C. Garcia and F. Espiei, Environ. Sci. Technol., 26, 1040 (1992)
33. C.H. Jung, T. Matsuto and N. Tanaka, Waste Manage., 25, 301 (2005).

34. S.G. Kim, The principles of mineralogy, Woosung Press (1996)

35. J.G. Jiang, X. Xu, J. Wang, S.J. Yang and Y. Zhang, J. Environ. Sci., 19, 458 (2007).

\section{ERRATUM}

Asian Journal of Chemistry

Vol. 25, No. 3 (2013), 1547-1554

\section{Thermal and Heavy Metal Ions Pollution Assessment in Near By Water Bodies of Vijayawada Thermal Power Station}

\section{Y. HANUMANTHA RAO ${ }^{1}$ and K. RAVINDHRANATH ${ }^{2, *}$}

${ }^{1}$ Andhra Loyola College (Autonomous), Vijayawada-520 008, India

${ }^{2}$ Department of Engineering Chemistry and Post Graduate Chemistry, Bapatla Engineering College, Bapatla-522 010, India

*Corresponding author: E-mail: ravindhranath.sita@yahoo.com

The following graphs are missed. Kindly see the graphs:

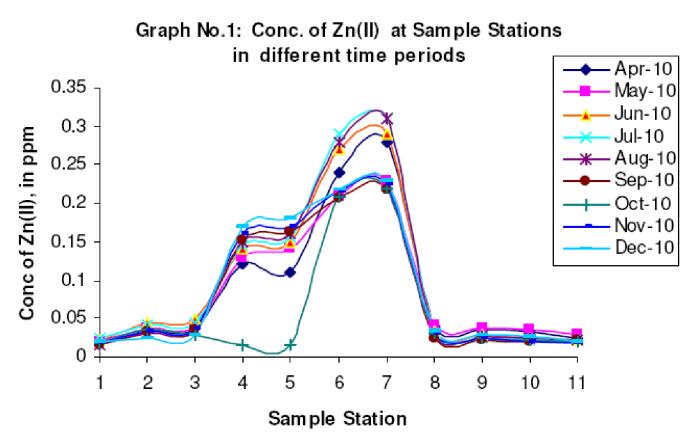

Graph No:3: Conc. of Ni(II) at Sample Stations in different time periods

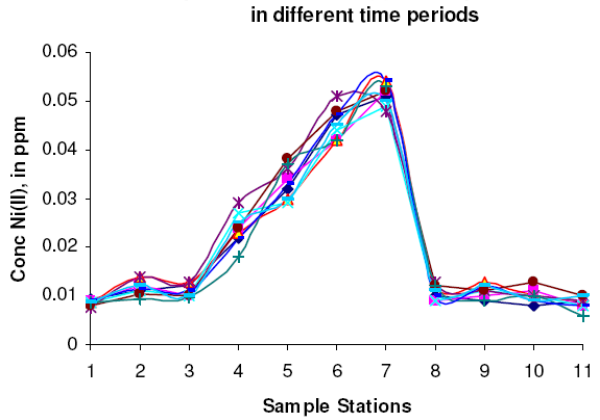

Fig No.5: Conc of Mn(II) at Sample Stations in different time periods

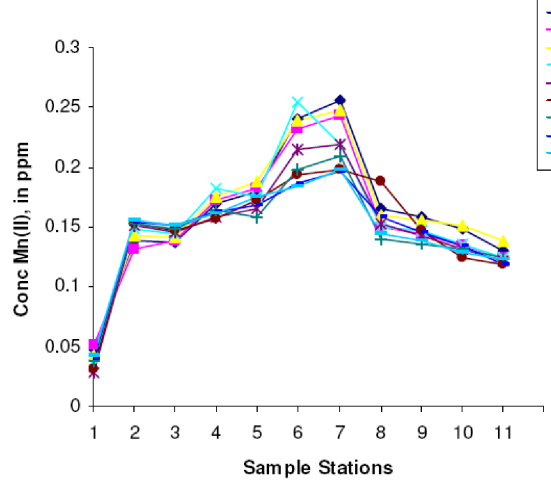

Graph No.:2: Conc of $\mathrm{Cu}(\mathrm{II})$ at Sample Stations in different time periods

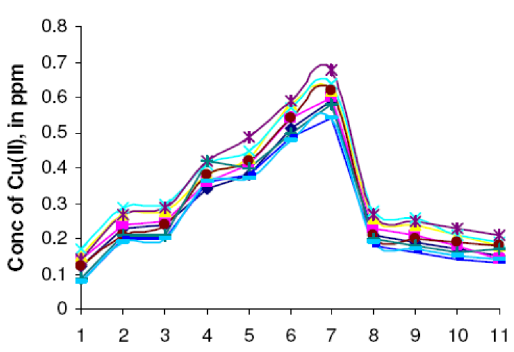

Sample Stations

Graph No. 4: Conc of Fe at Sample Stations in different time periods
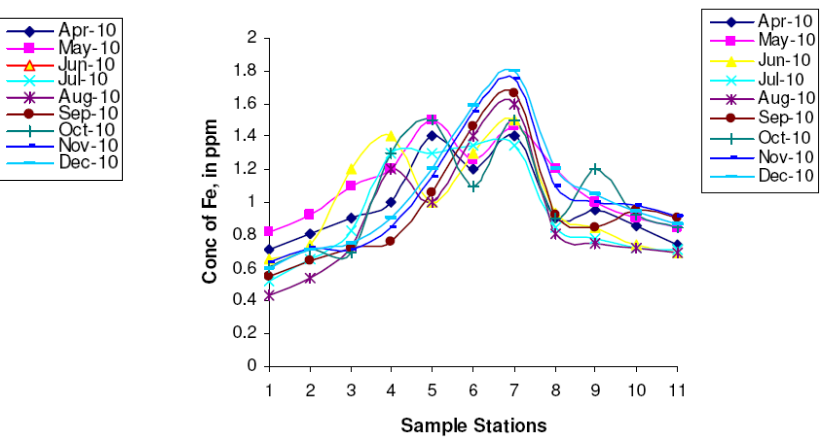

Fig No.6: Conc of Chromium at Sample Station in different time periods
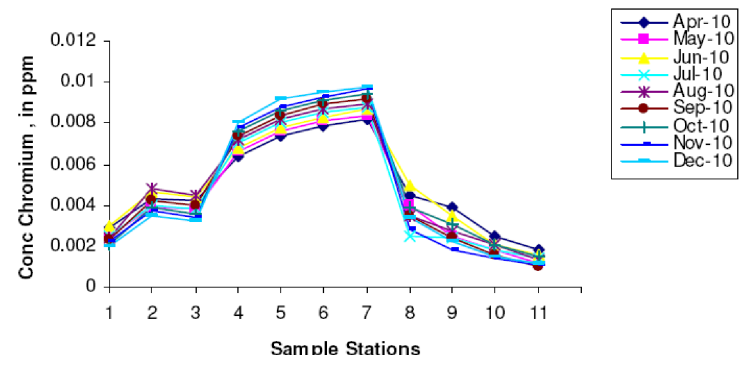